\title{
The Proteomics of Drusen
}

\author{
John W. Crabb \\ Cole Eye Institute, Cleveland Clinic, Cleveland, Ohio 44195 \\ Correspondence: crabbj@ccf.org
}

The formation of extracellular deposits known as drusen below the macular region of the retina correlates with increased risk of severe visual loss from age-related macular degeneration (AMD). Inflammation and complement dysregulation contribute to AMD progression; however, disease mechanisms remain incompletely defined. Multiple genetic and environmental factors influence AMD pathology, and although immune system processes play a central role, multiple molecular mechanisms appear to be involved. Drusen proteomics, including the analyses of constituent proteins, oxidative protein modifications, and pattern recognition receptors, provide a foundation for deciphering mechanisms of drusen biogenesis and AMD pathology.

$\mathrm{D}$ rusen are extracellular deposits of debris that accumulate with age on Bruch's membrane below the retinal pigment epithelium (RPE) and are considered clinical hallmarks of age-related macular degeneration (AMD). AMD, the leading cause of blindness in the elderly worldwide, is a complex disease involving inflammation and, in part, dysregulation of the complement system (Jager et al. 2008; Ding et al. 2009; Anderson et al. 2010). To date, 19 genetic loci (Fritsche et al. 2013) and multiple environmental factors, including diet and smoking, have been associated with AMD risk (Jager et al. 2008; Ding et al. 2009). Clinicians refer to drusen as either "soft" or "hard" in describing their relative shape and size, with hard drusen being nodular and generally smaller than soft drusen, which have a more diffuse appearance (Hageman et al. 2001). The presence of numerous and/or confluent soft drusen in the macula is considered a major risk factor for develop- ment of advanced AMD with severe visual loss (Fig. 1 ). Only $10 \%-20 \%$ of cases of early $/$ midstage AMD (also known as "dry" AMD) progress to advanced AMD, with neovascular or "wet" AMD (characterized by choroidal neovascularization) being the more prevalent form of advanced AMD (Ferris et al. 1984; Zarbin 2004). Geographic atrophy, also known as advanced dry AMD, is characterized by focal atrophy of the RPE and loss of macular photoreceptors, whereas choroidal neovascularization involves abnormal blood vessel growth from the choriocapillaris through the RPE, resulting in possible hemorrhage, exudation, scarring, and/or retinal detachment. It is possible for the two forms of advanced AMD to occur at the same time in separate eyes of an individual. Antivascular endothelial growth factor (VEGF) treatments can slow the progression of choroidal neovascularization (Jager et al. 2008), but universally effective therapies for geographic at-

Editors: Eric A. Pierce, Richard H. Masland, and Joan W. Miller

Additional Perspectives on Retinal Disorders: Genetic Approaches to Diagnosis and Treatment available at

www.perspectivesinmedicine.org

Copyright (C) 2014 Cold Spring Harbor Laboratory Press; all rights reserved

Advanced Online Article. Cite this article as Cold Spring Harb Perspect Med doi: 10.1101/cshperspect.a017194 
J.W. Crabb
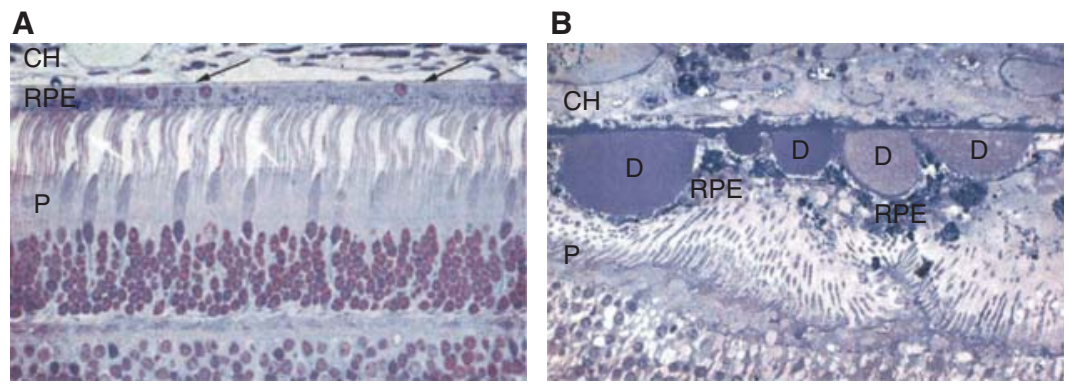

Figure 1. Comparison of ocular tissues containing drusen from normal eyes and eyes from AMD patients. In the normal retina $(A)$, the photoreceptor cells $(\mathrm{P})$ are highly organized, and their light-sensitive outer segments (white arrows) are in close contact with the RPE. Bruch's membrane (dark arrows), a thin layer of extracellular matrix between the RPE and choriocapillaris $(\mathrm{CH})$, is barely visible at this magnification. In the AMD retina $(B)$, photoreceptors are highly disorganized because of the presence of drusen (D), which also distorts the RPE and Bruch's membrane. (From Bok 2002; reproduced, with permission from National Academy of Sciences USA (C) 2002.)

rophy or for the prevention of wet or dry AMD have yet to be developed.

Drusen are widely accepted as contributors to the progression of AMD but the molecular mechanics of drusen formation are not yet well defined. Many components of drusen have been identified however the details of drusen biogenesis continue to be sought for molecular insights into AMD prevention and therapy. Histochemical and immunohistochemical studies have shown that drusen contain a variety of lipids, polysaccharides, glycosaminoglycans and proteins (Abdelsalam et al. 1999; Hageman et al. 1999, 2001; Kamei and Hollyfield 1999; Mullins et al. 2000; Malek et al. 2003; Anderson et al. 2004; Curcio et al. 2005a,b; Luibl et al. 2006; Wang et al. 2010; Jiang et al. 2012). Proteomic studies, both qualitative and quantitative, have expanded the repertoire of proteins and protein modifications associated with drusen (Crabb et al. 2002a; Umeda et al. 2005; Yuan et al. 2010; Garland et al. 2013). This review focuses on the proteomic components of drusen, and their potential impacts on drusen biogenesis and AMD pathology.

\section{QUALITATIVE PROTEOMIC STUDIES}

By the year 2000, about 20 protein components of human drusen had been identified by immunohistochemistry, including several immune system proteins, leading to the hypothesis that drusen formation involves inflammatory and immune responses to RPE damage (Hageman et al. 1999; Johnson et al. 2000; Mullins et al. 2000). In 2002, unbiased proteomic analysis by liquid chromatography tandem mass spectrometry (LC MS/MS) identified 129 proteins from isolated human drusen (Crabb et al. 2002a). Drusen are often found in the retinal periphery of normal aged eyes, and this early qualitative proteomic analysis included drusen isolated from 18 normal donors and 5 AMD donors. Based on the frequency of detection, common proteins found in both AMD drusen and normal donor drusen included tissue inhibitor of metalloproteinase 3 (TIMP3), clusterin, vitronectin, serum albumin, and crystallins, with crystallins detected more frequently in AMD donor drusen than in normal donor drusen. Significant proteomic heterogeneity was also apparent, with about a third of the proteins detected in AMD drusen not observed in normal donor drusen. To date, this study remains the only reported LC MS/MS proteomic comparison of human drusen purified from AMD eyes and normal eyes, in part because of the difficulty in obtaining AMD specimens and to the laborious drusen isolation procedure (Crabb et al. 2002a). Another mass spectrometric study has identified 60 proteins from drusen isolated from cynomolgus monkeys (Macaca fascicula- 
ris) exhibiting macular degeneration (Umeda et al. 2005). About $50 \%$ of the monkey proteins were identical to or homologous with human drusen components. The currently identified proteins from isolated primate drusen constitute a subset of the drusen proteome, as many other proteins could be present as shown by the quantitative proteomic studies discussed below.

Immunocytochemical evidence has corroborated the drusen localization of several of the proteins identified by LC MS/MS, including annexins I and VI, proteins S100 A7, S100 A8, and S100 A9 (Crabb et al. 2002a), clusterin (Sakaguchi et al. 2002), TIMP3 (Kamei and Hollyfield 1999), vitronectin (Hageman et al. 1999), amyloid A, amyloid P, $\alpha 1$-antitrypsin, $\alpha 1$-antichymotrypsin, apolipoprotein A1, apolipoprotein E (APOE), multiple complement components (C3, C5, and C9), fibrinogen, immunoglobulin $\kappa$, immunoglobulin $\lambda$, and ubiquitin (Mullins et al. 2000). Annexin II, identified by LC MS/ MS, was localized to the basal plasma membrane of the RPE adhering to drusen (Crabb et al. 2002a). Among the primate drusen proteins identified by LC MS/MS, it is possible that others may also belong to the RPE or Bruch's membrane. Nevertheless, this proteome supports the idea that drusen proteins come from several sources including the RPE, choroidal vasculature (Hageman et al. 2001; Penfold et al. 2001), and the systemic circulation.

\section{QUANTITATIVE PROTEOMIC STUDIES}

Two quantitative proteomic studies provide additional insights into mechanisms of drusen formation and macular degeneration. These studies include an analysis of the macular region of the Bruch's membrane/choroid complex from human AMD donors and normal donors (Yuan et al. 2010), and a proteomic analysis of Bruch's membrane/choroid from a mouse model of Doyne honeycomb retinal dystrophy/malattia Leventinese (Garland et al. 2013). Bruch's membrane is an important extracellular, semipermeable support for the RPE, influences the diffusion of nutrients and waste products between the RPE and the choroidal bloodstream, and restricts cell migration (Goldberg 1976). It is composed of the basement membranes of the RPE and choriocapillaris, inner and outer collagenous layers, and a central elastin zone (Booij et al. 2010). AMD pathology typically involves thickening and decreased permeability of Bruch's membrane (Goldberg 1976), thought to be caused in part by accumulation of collagen, lipids, advanced glycation endproducts (AGEs), RPE waste products and cross-links that covalently trap debris (Booij et al. 2010).

\section{AMD-Associated Protein Alterations in Human Macular Bruch's Membrane/Choroid}

LC MS/MS isobaric tags for relative and absolute quantitation (iTRAQ) technology has been used to quantify proteins in the macular region of the Bruch's membrane/choroid complex from human postmortem eyes (10 with early/ mid dry AMD, six with advanced dry AMD, eight with wet AMD, and 25 normal eyes) (Yuan et al. 2010). A total of 901 proteins was quantified, the majority of which differed little in amount between AMD and controls and thus provide a partial proteome of normal human macular tissues of average age 81 . Ninety-nine proteins were identified with significantly altered amounts in AMD macular tissues relative to normal controls, including 56 elevated and 43 reduced proteins. Consistent with proposed mechanisms of Bruch's membrane thickening (Booij et al. 2010), the relative amounts of 13 different collagens and protein-glutamine $\gamma$-glutamyltransferase 2, a cross-linking enzyme, were elevated in AMD tissues (Yuan et al. 2010). About $60 \%$ of the elevated proteins were immune response and host defense proteins, including many complement proteins and complement-associated proteins (e.g., C3, C4A, C5, C6, C7, C8y, C9, complement factor B, complement factor $\mathrm{H}(\mathrm{CFH})$, and clusterin). Also among the elevated proteins were several damage-associated molecular pattern proteins (DAMPs) such as $\alpha$-defensins $1-3$, protein S100-A8, protein S100-A9, $\alpha$-crystallin A, $\alpha$ crystallin $\mathrm{B}$, histones and galectin-3. DAMPs are endogenous proteins released by damaged cells and capable of activating pattern recognition receptors (Lotze et al. 2007). Not surpris- 
J.W. Crabb

ingly, several proteins identified in isolated drusen were elevated in the macular AMD tissues (Table 1).

Inflammatory response proteins were found to be elevated in multiple categories of AMD progression, supporting the idea that inflammatory processes are involved in both initiating events of AMD and progression to advanced AMD. Four retinoid processing proteins (retinal pigment epithelium-specific $65 \mathrm{kDa}$ protein, cellular retinoic acid-binding protein 1, cellular retinaldehyde binding protein, and interphotoreceptor retinoid binding protein) were found uniquely elevated in early/mid stage AMD, suggesting that retinoid metabolism contributes to AMD initiation, likely through mechanisms involving RPE lipofuscin (Eldred and Lasky 1993; Sakai et al. 1996; Sparrow and Boulton 2005; Kim et al. 2007; Sparrow 2007; Ng et al. 2008; Wu et al. 2010). AGE receptor 3 (also known as galectin-3) was the most significantly elevated protein in advanced dry AMD, implicating a role for AGEs in geographic atrophy. The remaining $\sim 40 \%$ of the elevated proteins were associated with other regulatory functions and specialized metabolic or housekeeping processes. Elevated regulatory proteins included the protease inhibitors TIMP3 and $\alpha$-1-microglobulin as well as pigment epithelium-derived factor, a neurotrophic antiangiogenic protein, all of which were also detected in purified drusen (Crabb et al. 2002a). Other elevated regulatory proteins in macular Bruch's/choroid included phosphatidylethanol-amine binding protein 1 , a serine protease inhibitor; Rho GDP-dissociation inhibitor 1, a cell adhesion regulator; reticulon-4, a cell migration regulator; and voltagedependent anion-selective channel protein 3, a diffusion regulator of small molecules. Consistent with proposed roles for mitochondrial dysfunction in aging (Knott et al. 2008) and AMD pathology (Nordgaard et al. 2008), mitochondrial cytochrome c oxidase subunit 5B, 2-oxoglutarate/malate carrier protein, and mitochondrial aldehyde dehydrogenase were elevated in the macular AMD Bruch's membrane/choroid complex in AMD.

Significantly reduced proteins accounted for a small fraction $(<2 \%)$ of the proteins quan- tified in the macular region of the Bruch's/choroid complex in AMD. Over half of these proteins can be associated with cell adhesion and protein interactions (asporin, nidogen-2, Protein FAM 10A4, CD9), or vascularization and angiogenesis (tryptase $\alpha 1$, plasmalemma vesicle associated protein, caveolin-1, $\beta 2$-glycoprotein 1). Proteins decreased only in early $/ \mathrm{mid}$ stage AMD implicate hematologic malfunctions, reduced extracellular matrix integrity, and weakened cellular interactions. Proteins uniquely decreased in advanced dry AMD included $\beta$ crystallin B2, carbonic anhydrase 4, ubiquitin, and haptoglobin. Neuroblast differentiation-associated protein, a membrane remodeling and repair protein also known as desmoyokin, was decreased in advanced dry AMD but elevated in neovascular AMD. Proteins uniquely reduced in neovascular AMD included two histones, CD 9, three glycolytic enzymes, mitochondrial trifunctional enzyme $\beta$, creatine kinase $B$ and ferritin light chain. Interphotorecepetor retinoid binding protein was reduced in both advanced dry and wet AMD. While reduced protein abundance in advanced AMD could reflect disease consequences (e.g., cell death), the majority of elevated proteins were different in geographic atrophy compared with neovascular AMD, implicating multiple mechanisms of AMD progression.

\section{Proteins in the Bruch's Membrane/Choroid in Efemp $1^{\mathrm{R} 345 \mathrm{~W} / \mathrm{R} 345 \mathrm{~W}}$ Mice}

Doyne honeycomb retinal dystrophy/malattia Leventinese is an inherited macular dystrophy caused by a point mutation (R345W) in the gene that encodes epidermal growth-factor-containing fibulin-like extracellular matrix protein 1 (EFEMP1), yielding a human phenotype similar to dry AMD with extensive drusen (Stone et al. 1999, 2004; Marmorstein 2002; Michaelides et al. 2006; Fu et al. 2007). Gene-targeted Efemp $1^{R 345 W / R 345 W}$ mice provide an animal model that with age exhibit a macular degeneration-like phenotype and extensive formation of extracellular basal laminar deposits under the RPE ( Fu et al. 2007; Marmorstein et al. 2007). Such basal deposits have long been con- 
The Proteomics of Drusen
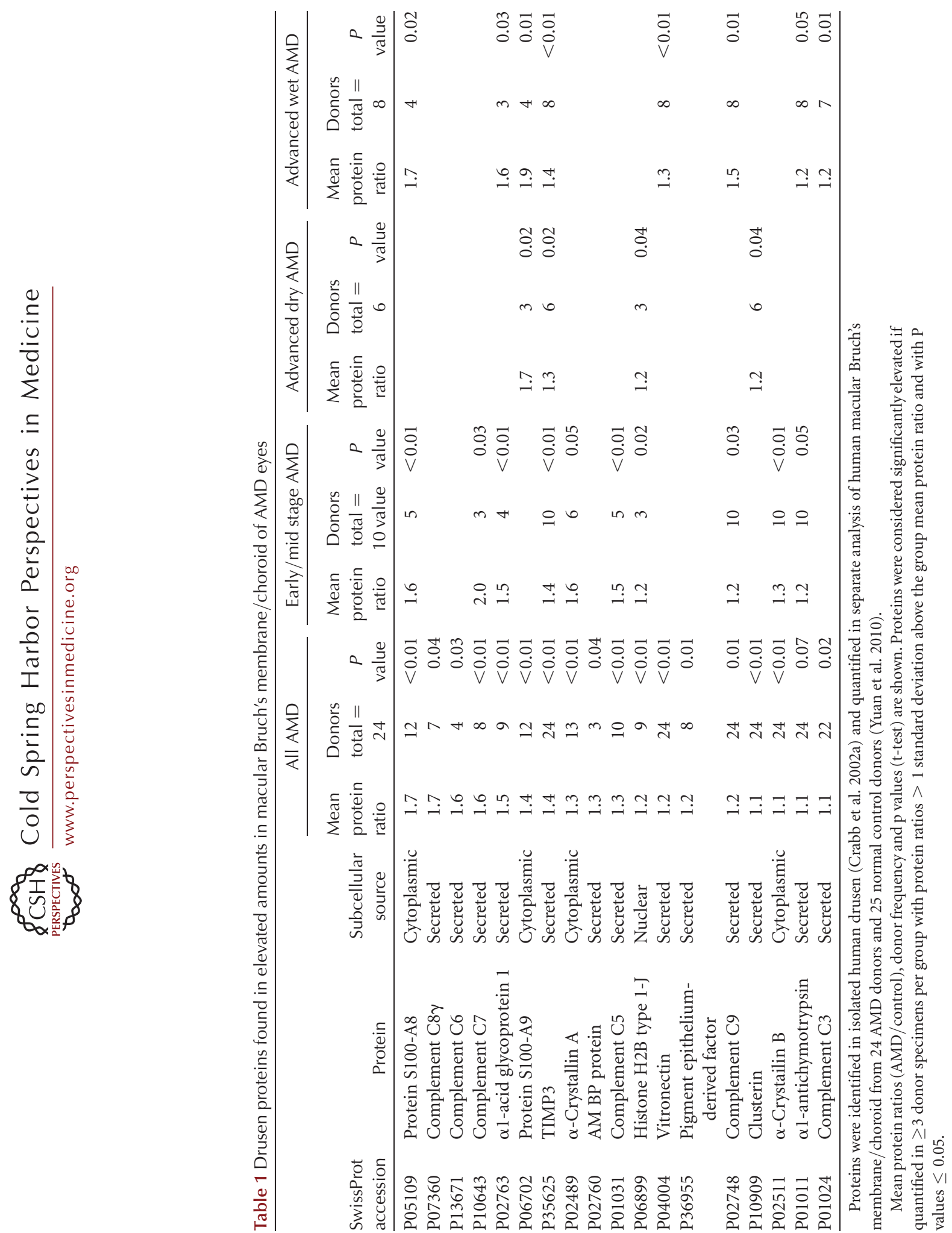
J.W. Crabb

sidered potential precursors of drusen (Sarks 1976; Green and Enger 1993; Spraul and Grossniklaus 1997; Curcio and Millican 1999; Sarks et al. 2007).

Quantitative proteomic analysis of basal deposits in the Efemp $1^{R 345 W / R 345 W}$ mouse model has revealed important clues to mechanisms of basal deposit formation (Garland et al. 2013). Bruch's membrane/choroid specimens from three ages of mutant and control mice $(8,14$, and $24 \mathrm{mo}$ ) were analyzed to detect protein changes from early through extensive basal deposit formation. Bruch's membrane specimens without RPE or choroid were analyzed at $24 \mathrm{mo}$ to more closely measure the basal deposit proteome. About 780 proteins per animal were identified, yielding a total of 1062 proteins quantified using LC MS/MS spectral counting methods. Major changes in protein abundance in the mutant mice were found associated with immune system processes. Notably, 11 complement components were detected in the samples from $E f e m p 1^{R 345 W / R 345 W}$ mice, with significant increases relative to controls in the abundance of complement components C3 and C4 in both 24-mo Bruch's membrane samples and in Bruch's/choroid specimens by 14 mo. The functional role of the complement system in basal deposit formation was further tested by generating homozygous Efemp1 $1^{R 345 W / R 345 W}: C 3^{-/-}$ double mutant mice that expressed the R345W point mutation but lacked C3 expression. Histological analyses showed that basal deposits were markedly reduced in the double mutant mice, demonstrating that an active complement system plays an important role in basal deposit formation in this mouse model. The molecular details of this process, however, remain to be determined.

Quantitative proteomic changes in Efemp $1^{R 345 W / R 345 W}$ mutant mice highlighted three other major biological processes that potentially contribute to basal deposit formation, namely cell-cell and cell-matrix adhesion, signal transduction, and intracellular transport (Garland et al. 2013). Four proteins exhibiting large increases in the Bruch's membrane of mutant mice and of possible pathological significance were EFEMP1, thrombospondin 1, milk- fat globule-EGF factor 8, and collagen VI, each of which can be associated with multiple processes and/or extracellular matrix structure function. No new or unusual proteins were identified, suggesting that normal extracellular matrix components in altered amounts or structure contribute to basal deposit formation. Similarities in the proteomic results from Bruch's membrane/choroid from Efemp1 $1^{R 345 W / R 345 W}$ mice (Garland et al. 2013) and human AMD donors (Yuan et al. 2010) were significant. About $50 \%$ of the proteins identified in the human study were also detected in the mouse samples, with remarkable quantitative agreement between select proteins, including C3, C4, vitronectin, galectin -3 , and $\operatorname{Ig} \mu$ chain $\mathrm{C}$ region, which were increased in both advanced AMD patients and the mutant mice.

\section{OXIDATIVE PROTEIN MODIFICATIONS IN DRUSEN}

Oxidative stress has long been considered a major contributor to AMD pathology (Seddon et al. 1996; Beatty et al. 2000; AREDS 2001; Hageman et al. 2001). Because of high oxygen tension and light exposure, the RPE/Bruch's/ choroid interface is an extreme environment that facilitates the production of reactive oxygen species and nitrogen species that can stimulate inflammatory and immune responses (Verhasselt et al. 1998; Matsue et al. 2003; Hazen 2008; Hagenow et al. 2009). Moreover, in this extreme environment, photoreceptor outer segment tips phagocytized daily by the RPE are highly susceptible to oxidation, resulting in the production of reactive cleavage fragments from lipids, sugars, and retinoids, and subsequent oxidative modifications. A host of elevated protein modifications derived from lipoxidation and glycoxidation have been associated with AMD ocular tissues (Crabb 2012), and several have been demonstrated in drusen.

Oxidative protein modifications have the potential to mask proteolytic cleavage sites, inactivate enzymes (Crabb et al. 2002b), and contribute to the accumulation of cross-linked intracellular debris that copurifies with RPE lipofuscin granules (Chio et al. 1969; Schutt et al. 
2003; Ng et al. 2008) and with extracellular debris in drusen (Crabb et al. 2002a). For example, several drusen proteins have been shown to migrate in multiple mass ranges in SDS gel electrophoresis, from the top to the bottom of the gel (Crabb et al. 2002a). The higher-mass components containing TIMP3, vitronectin, and C9 suggest the presence of covalent cross-links caused by reactive oxidation fragments from lipids and/or carbohydrates (Friguet et al. 1994; Elgawish et al. 1996).

Carboxymethyllysine was the first oxidative protein modification reported in drusen (Fig. 2 ). Greater immunoreactivity for carboxymethyllysine was detected in basal laminar and basal linear deposits, soft macular drusen, and choroidal neovascular membranes from AMD eyes compared to control eyes (Ishibashi et al. 1998). Carboxymethyllysine is a lysine glycoxidation modification formed through the nonenzymatic Maillard reaction, which combines sugar carbonyls with primary amino groups to form Amadori products. Amadori products un- dergo subsequent nonenzymatic reactions, including oxidative decomposition, to form a heterogeneous group of modifications known as AGEs (Baynes 2001). The presence of AGEs in aging ocular tissues is well-established (Ishibashi et al. 1998; Farboud et al. 1999; Hammes et al. 1999; Handa et al. 1999; Crabb et al. 2002a; Howes et al. 2004; Glenn et al. 2007, 2009). Pentosidine, another AGE in drusen, forms fluorescent lysine-arginine cross-links (Handa et al. 1999; Glenn et al. 2007). Advanced glycation occurs slowly over time, and long-lived proteins (e.g., collagens) in extracellular matrices such as Bruch's membrane are particularly susceptible to modification. AGE modifications promote protein denaturation, decreased solubility, decreased flexibility, and increased resistance to proteolytic degradation. Several studies have demonstrated that carboxymethyllysine induces VEGF expression in vitro in a variety of cell types, (Hirata et al. 1997; Lu et al. 1998; Treins et al. 2001; Hoffmann et al. 2002; Urata et al. 2002) and stimulates neovascularization in vivo
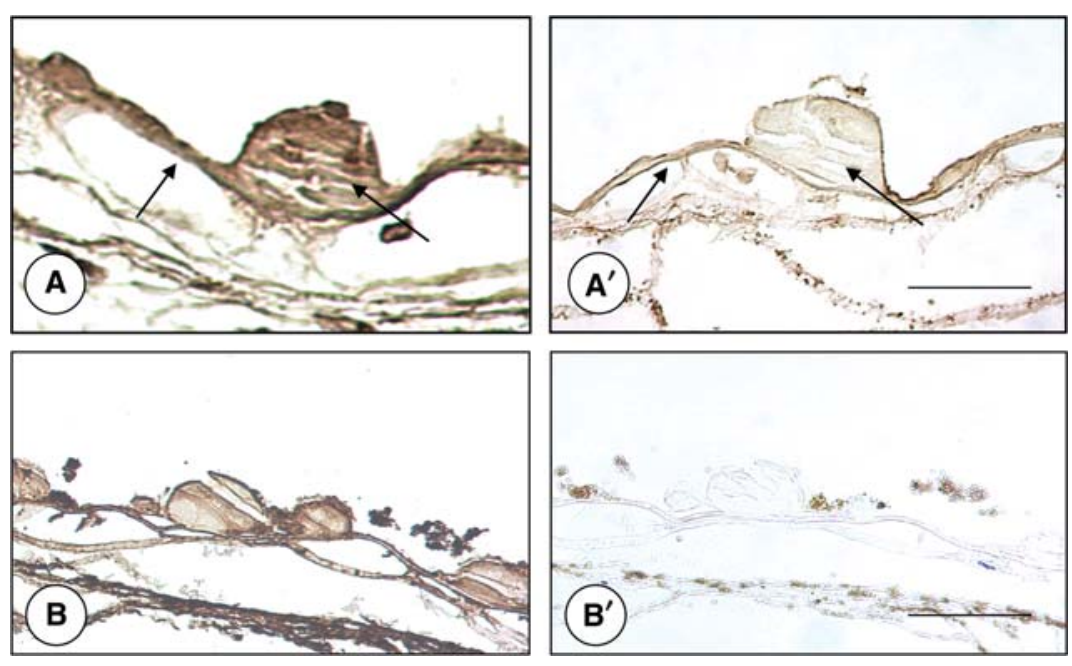

Figure 2. Oxidative Protein Modifications in Human Drusen and Bruch's Membrane. (A) Immunohistochemical analysis of Bruch's membrane/choroid tissue with anticarboxyethylpyrrole monoclonal antibody. $\left(A^{\prime}\right)$ Control section, probed with preimmune IgG. (Arrows indicate Bruch's membrane and drusen; scale bar, $50 \mu \mathrm{m})$. (B) Immunohistochemical analysis with anticarboxymethyllysine monoclonal antibody. ( $B^{\prime}$ ) Control consecutive section treated with normal mouse IgG. This figure demonstrates the lipoxidation product carboxyethylpyrrole and the glycoxidation product carboxymethyllysine associated with drusen and Bruch's membrane. (Scale bar, $50 \mu \mathrm{m}$ ). (From Crabb et al. 2002a; reproduced, with permission from National Academy of Sciences USA (C) 2002.) 
J.W. Crabb

(Okamoto et al. 2002). Plasma levels of both carboxymethyllysine and pentosidine are elevated in AMD (Ni et al. 2009).

Several receptors modulate the biological effects of AGEs (Goh and Cooper 2008), including receptor of AGEs (RAGE), a pattern-recognition receptor that binds a variety of ligands, including DAMPs. RAGE ligands vary in their proinflammatory potential, but carboxymethyllysine is a strong inducer of RAGE signaling (Herold et al. 2007). Drusen proteins S100A8 and S100A9 (Crabb et al. 2002a; Yuan et al. 2010) are DAMPs thought to be activators of RAGE (Sparvero et al. 2009). Treatment of cultured RPE cells with AGEs, including carboxymethyllysine, has been shown to upregulate RAGE, resulting in apoptotic RPE cell death (Howes et al. 2004).

Multiple lipoxidation products are present in drusen, Bruch's membrane, and the cellular debris that copurifies with RPE lipofuscin granules (Crabb et al. 2002a; Gu et al. 2003a; Schutt et al. 2003; Shen et al. 2007; Ng et al. 2008; Weismann et al. 2011; Shaw et al. 2012). Lipoxidation in drusen is not surprising given the high amounts of cholesterol esters and phospholipids in drusen (Wang et al. 2010). Reactive lipid fragments can form Schiff base linkages with primary amino groups, resulting in the formation of a variety of adducts (Esterbauer et al. 1991; Gu et al. 2003b). Carboxyethylpyrrole was the first lipoxidation product identified in drusen (Fig. 2) and has been shown to be significantly more abundant in AMD ocular tissues and blood than in normal tissues (Crabb et al. 2002a; Gu et al. 2009). Carboxyethylpyrrole adducts are generated by the covalent reaction of primary amino groups (e.g., protein $\varepsilon$-lysyl $\mathrm{NH}_{2}$ ) with 4-hydroxy-7-oxohept-5-enoic acid, a reactive fragment derived uniquely from oxidative cleavage of docosahexaenoate (DHA)containing lipids ( $\mathrm{Gu}$ et al. 2003b). DHA is abundant in the retina (Fliesler and Anderson 1983) and concentrated in the photoreceptor outer segments and the RPE (Wang and Anderson 1992; Alvarez et al. 1994). Mass spectrometric analysis of carboxyethylpyrrole-immunoreactive 2D gel spots has identified albumin and $\alpha 1$-antitrypsin as likely carboxyethylpyrrole- modified proteins in the Bruch's membrane/ choroid/RPE complex in AMD; both of these proteins have been found in drusen (Crabb et al. 2002a).

Carboxyethylpyrrole adducts stimulate angiogenesis in vivo through toll-like receptor 2 (TLR2), another pattern recognition receptor. In contrast to neovascularization induced by carboxymethyllysine, carboxyethylpyrrole stimulates angiogenesis independent of VEGF (Ebrahem et al. 2006; West et al. 2010). Similar to complement and RAGE, TLR2 binds multiple ligands and initiates inflammatory and immune responses (Zahringer et al. 2008). At low concentrations, carboxyethylpyrrole adducts are hypothesized to contribute to wound healing, but at high concentrations may catalyze amplified TLR2 signaling and excessive neovascularization (West et al. 2010). Carboxyethylpyrrole protein adducts have also been shown to promote platelet activation and aggregation in vitro and thrombosis in vivo through tolllike receptor 9 (TLR9) (Panigrahi et al. 2013). Mice immunized with carboxyethylpyrrole-adducted mouse albumin develop focal changes in the RPE resembling those in advanced dry AMD, exhibit monocyte and macrophage migration into the interphotoreceptor matrix and also exhibit elevated complement deposition in Bruch's membrane (Hollyfield et al. 2008). Carboxyethylpyrrole adducts appear to be initiators of immune responses capable of contributing to either dry or wet AMD-like phenotypes.

Other lipoxidation products in drusen appear to be ligands for CFH, including malondialdehyde (Weismann et al. 2011) and 1-palmitoyl-2-(5'-oxo-valeroyl)-sn-glycero-3-phosphocholine (POVPC) (Shaw et al. 2012). CFH exhibiting the AMD risk $402 \mathrm{H}$ polymorphism was found to bind malondialdehyde or POVPC with less affinity than the CFH 402Y nonrisk variant (Weismann et al. 2011; Shaw et al. 2012). These independent studies also reported that inflammatory responses stimulated by malondialdehyde and POVPC in vitro and in vivo were stronger with the AMD risk variant of $\mathrm{CFH}$ than with the nonrisk CFH isoform, suggesting that the nonrisk isoform may help dampen inflammatory responses induced by oxidative 
modifications. These observations add support to the hypothesized central role of oxidative modifications in the pathology of AMD and justify further mechanistic studies.

\section{DRUSEN FORMATION}

Immune-mediated events have long been thought to play a role in drusen formation due to the presence of proteins in drusen upregulated during inflammatory responses (Johnson et al. 2000; Hageman et al. 2001). Growing evidence supports this hypothesis. Consistent with early drusen studies, several genes involved in inflammation, and/or the immune system have now been associated with AMD risk. These include CFH (Edwards et al. 2005; Hageman et al. 2005; Haines et al. 2005; Klein et al. 2005), complement factor B (Gold et al. 2006), complement C3 (Yates et al. 2007), APOE (Zareparsi et al. 2004; Baird et al. 2006), toll-like receptor 4 (Zareparsi et al. 2005), LOC387715/ ARMS2 (Rivera et al. 2005; Kanda et al. 2007), HTRA1 (Dewan et al. 2006; Yang et al. 2006), and ABCA4 (Allikmets 2000). In a human RPE cell culture model mimicking early AMD, drusen biogenesis was reported to involve select serum protein interactions with APOE-rich sub-RPE deposits, which subsequently activate the complement cascade and the deposition of complement complexes (Johnson et al. 2011). Amyloid $\beta$ ( $A \beta)$ may also play a role in drusen formation (Johnson 2002; Dentchev et al. 2003; Anderson et al. 2004; Luibl et al. 2006; Isas et al. 2010). Notably, drusen-like deposits develop below the RPE following $A \beta$ treatment of mice lacking the $A \beta$-degrading enzyme neprilysin (Yoshida et al. 2005). In the human APOE4knockin mouse model of $\mathrm{AMD}, \mathrm{A} \beta$ is found in sub-RPE deposits and neovascular lesions (Malek et al. 2005; Ding et al. 2008), and antiA $\beta$ therapy blocks histopathologic changes (Ding et al. 2011). In human drusen, $A \beta$ has been colocalized with activated complement (Johnson 2002; Dentchev et al. 2003; Anderson et al. 2004). A $\beta$ has also been reported to activate complement (Rogers et al. 1992; Jiang et al. 1994) and other pattern recognition receptors, including RAGE (Chen et al. 2007; Schmidt et al. 2009) and toll-like receptors (Fassbender et al. 2004; Liu et al. 2005). As recently reported and described above, an active complement system has an important function in basal deposit formation in Efemp1 $1^{R 345 W / R 345 W}$ mutant mice (Garland et al. 2013). While specific molecular mechanisms remain to be defined, immune system processes appear to play a major role in drusen formation.

\section{CONCLUDING REMARKS}

Drusen, when concentrated on Bruch's membrane in the macular region, are major risk factors for AMD progression to advanced disease. Early immunohistochemical studies suggested that inflammatory and immune response processes after RPE injury contribute to drusen formation, a hypothesis that has gained significant support. Qualitative proteomic analysis of isolated drusen using mass spectrometry has made important contributions toward understanding drusen formation, including the identification of multiple immune responses and cellular defense proteins, and support for multiple sources of drusen components, including the RPE, choroidal vasculature, and the systemic circulation. Quantitative proteomic analysis of the human Bruch's membrane/choroid complex has identified 99 proteins significantly altered in abundance in the macular region of AMD tissues, many of which are involved in immune system and cellular defense processes, and also were previously identified in isolated human drusen. Quantitative proteomics and genomics have also demonstrated a critical role for the complement system in basal deposit formation in a mouse model of Doyne honeycomb retinal dystrophy/malattia Leventinese, with remarkable quantitative agreement between select proteins from human and mouse Bruch's membrane/ choroid complex. Double mutant mice expressing the disease-causing variant of EFEMP1 protein but not expressing C3 exhibited markedly reduced basal deposit formation, demonstrating that in this mouse model, the immune system plays a major role in basal deposit formation.

Immune system processes involving pattern recognition receptors other than the comple- 
J.W. Crabb

ment system may also contribute to AMD pathology. Several studies have shown that drusen and ocular tissues from AMD donors contain a variety of oxidative protein modifications, including lipoxidation products (e.g., carboxyethylpyrrole, malondialdehyde, and POVPC), glycoxidation products (e.g., carboxymethyllysine and pentosidine), and protein cross-links. Whereas $\mathrm{CFH}$ has been reported to bind malondialdehyde and POVPC, oxidative modifications such as carboxymethyllysine and carboxyethylpyrrole trigger immune responses through other pattern recognition receptors such as RAGE, TLR2, and TLR9. Drusen and the macular Bruch's membrane/choroid complex from AMD donors contain elevated levels of several DAMPS (e.g., protein S100s, crystallins, and histones) that may also trigger pattern recognition receptors. Other proteins such as $\mathrm{A} \beta$ and the cross-linking enzyme protein-glutamine $\gamma$-glutamyltransferase 2 also may have important roles in drusen formation. Multiple molecular mechanisms appear to be involved and more work is required to fully understand drusen biogenesis.

\section{ACKNOWLEDGMENTS}

Supported in part by NIH grants EY021840, EY022134, EY14239, EY15638, Ohio Biomedical Research Technology Transfer grant 05-29, a Research Center grant from The Foundation Fighting Blindness, an unrestricted grant from Research to Prevent Blindness (RPB), an RPB Senior Investigator Award, a Steinbach Award, and The Cleveland Clinic Foundation.

\section{REFERENCES}

Abdelsalam A, Del Priore L, Zarbin MA. 1999. Drusen in age-related macular degeneration: Pathogenesis, natural course, and laser photocoagulation-induced regression. Surv Ophthalmol 44: 1-29.

Age Related Eye Disease Study Group. 2001. A randomized, placebo-controlled, clinical trial of high-dose supplementation with vitamins $\mathrm{C}$ and $\mathrm{E}, \beta$ carotene, and zinc for age-related macular degeneration and vision loss: AREDS report no. 8. Arch Ophthalmol 119: 1417-1436.

Allikmets R. 2000. Further evidence for an association of $A B C R$ alleles with age-related macular degeneration.
The International ABCR Screening Consortium. Am J Hum Genet 67: 487-491.

Alvarez R, Aguirre G, Acland G, Anderson R. 1994. Docosapentaenoic acid is converted to docosahexaenoic acid in the retinas of normal and prcd-affected miniature poodle dogs. Invest Ophthalmol Vis Sci 35: 402-408.

Anderson DH, Talaga KC, Rivest AJ, Barron E, Hageman GS, Johnson LV. 2004. Characterization of $\beta$ amyloid assemblies in drusen: The deposits associated with aging and age-related macular degeneration. Exp Eye Res 78: $243-$ 256.

Anderson DH, Radeke MJ, Gallo NB, Chapin EA, Johnson PT, Curletti CR, Hancox LS, Hu J, Ebright JN, Malek G, et al. 2010. The pivotal role of the complement system in aging and age-related macular degeneration: Hypothesis re-visited. Prog Retin Eye Res 29: 95-112.

Baird PN, Richardson AJ, Robman LD, Dimitrov PN, Tikellis G, McCarty CA, Guymer RH. 2006. Apolipoprotein (APOE) gene is associated with progression of age-related macular degeneration (AMD). Hum Mutat 27: $337-$ 342.

Baynes JW. 2001. The role of AGEs in aging: Causation or correlation. Exp Gerontol 36: 1527-1537.

Beatty S, Koh H, Phil M, Henson D, Boulton M. 2000. The role of oxidative stress in the pathogenesis of age-related macular degeneration. Surv Ophthalmol 45: 115-134.

Bok D. 2002. New insights and new approaches toward the study of age-related macular degeneration. Proc Natl Acad Sci 99: 14619-14621.

Booij JC, Baas DC, Beisekeeva J, Gorgels TG, Bergen AA. 2010. The dynamic nature of Bruch's membrane. Prog Retin Eye Res 29: 1-18.

Chen X, Walker DG, Schmidt AM, Arancio O, Lue LF, Yan SD. 2007. RAGE: A potential target for $A \beta$-mediated cellular perturbation in Alzheimer's disease. Curr Mol Med 7: 735-742.

Chio KS, Reiss U, Fletcher B, Tappel AL. 1969. Peroxidation of subcellular organelles: Formation of lipofuscinlike fluorescent pigments. Science 166: 1535-1536.

Crabb JW. 2012. Oxidative modifications as triggers of AMD pathology. In Studies on Retinal and Choroidal Disorders (ed. Stratton R, Hauswirth W, Gardiner T), pp. 65-84. Humana Press.

Crabb JW, Miyagi M, Gu X, Shadrach K, West KA, Sakaguchi H, Kamei M, Hasan A, Yan L, Rayborn ME, et al. 2002a. Drusen proteome analysis: An approach to the etiology of age-related macular degeneration. Proc Natl Acad Sci 99: 14682-14687.

Crabb JW, O’Neil J, Miyagi M, West K, Hoff HF. 2002b. Hydroxynonenal inactivates cathepsin B by forming Michael adducts with active site residues. Protein Sci 11: 831-840.

Curcio CA, Millican CL. 1999. Basal linear deposit and large drusen are specific for early age-related maculopathy. Arch Ophthalmol 117: 329-339.

Curcio CA, Presley JB, Malek G, Medeiros NE, Avery DV, Kruth HS. 2005a. Esterified and unesterified cholesterol in drusen and basal deposits of eyes with age-related maculopathy. Exp Eye Res 81: 731-741.

Curcio CA, Presley JB, Millican CL, Medeiros NE. 2005b. Basal deposits and drusen in eyes with age-related mac- 
ulopathy: Evidence for solid lipid particles. Exp Eye Res 80: $761-775$.

Dentchev T, Milam AH, Lee VM, Trojanowski JQ, Dunaief JL. 2003. Amyloid- $\beta$ is found in drusen from some agerelated macular degeneration retinas, but not in drusen from normal retinas. Mol Vis 9: 184-190.

Dewan A, Liu M, Hartman S, Zhang S, Liu D, Zhao C, Tam P, Chan W, Lam D, Snyder M, et al. 2006. HTRAlpromoter polymorphism in wet age-related macular degeneration. Science 314: 989-992.

Ding X, Patel M, Chan CC. 2009. Molecular pathology of age-related macular degeneration. Prog Retin Eye Res 28: $1-18$.

Ding JD, Johnson LV, Herrmann R, Farsiu S, Smith SG, Groelle M, Mace BE, Sullivan P, Jamison JA, Kelly U, et al. 2011. Anti-amyloid therapy protects against retinal pigmented epithelium damage and vision loss in a model of age-related macular degeneration. Proc Natl Acad Sci 108: E279-E287.

Ding JD, Lin J, Mace BE, Herrmann R, Sullivan P, Bowes Rickman C. 2008. Targeting age-related macular degeneration with Alzheimer's disease based immunotherapies: Anti-amyloid- $\beta$ antibody attenuates pathologies in an age-related macular degeneration mouse model. Vision Res 48: 339-345.

Ebrahem Q, Renganathan K, Sears J, Vasanji A, Gu X, Lu L, Salomon RG, Crabb JW, Anand-Apte B. 2006. Carboxyethylpyrrole oxidative protein modifications stimulate neovascularization: Implications for age-related macular degeneration. Proc Natl Acad Sci 103: 13480-13484.

Edwards A, Ritter R, Abel K, Manning A, Panhuysen C, Farrer L. 2005. Complement factor H polymorphism and age-related macular degeneration. Science 308: 421-424.

Eldred GE, Lasky MR. 1993. Retinal age pigments generated by self-assembling lysosomotropic detergents. Nature 361: $724-726$.

Elgawish A, Glomb M, Friedlander M, Monnier VM. 1996. Involvement of hydrogen peroxide in collagen cross-linking by high glucose in vitro and in vivo. J Biol Chem 271: 12964-12971.

Esterbauer H, Schaur RJ, Zollner H. 1991. Chemistry and biochemistry of 4-hydroxynonenal, malonaldehyde and related aldehydes. Free Radic Biol Med 11: 81-128.

Farboud B, Aotaki-Keen A, Miyata T, Hjelmeland LM, Handa JT. 1999. Development of a polyclonal antibody with broad epitope specificity for advanced glycation endproducts and localization of these epitopes in Bruch's membrane of the aging eye. Mol Vis 5: 11.

Fassbender K, Walter S, Kuhl S, Landmann R, Ishii K, Bertsch T, Stalder AK, Muehlhauser F, Liu Y, Ulmer AJ, et al. 2004. The LPS receptor (CD14) links innate immunity with Alzheimer's disease. FASEB J 18: 203-205.

Ferris FL III, Fine SL, Hyman L. 1984. Age-related macular degeneration and blindness due to neovascular maculopathy. Arch Ophthalmol 102: 1640-1642.

Fliesler SJ, Anderson RE. 1983. Chemistry and metabolism of lipids in the vertebrate retina. Prog Lipid Res 22: 79131.

Friguet B, Stadtman ER, Szweda LI. 1994. Modification of glucose-6-phosphate dehydrogenase by 4-hydroxy-2- nonenal. Formation of cross-linked protein that inhibits the multicatalytic protease. J Biol Chem 269: 2163921643.

Fritsche LG, Chen W, Schu M, Yaspan BL, Yu Y, Thorleifsson G, Zack DJ, Arakawa S, Cipriani V, Ripke S, et al. 2013. Seven new loci associated with age-related macular degeneration. Nat Genet 45: 433-439.

Fu L, Garland D, Yang Z, Shukla D, Rajendran A, Pearson E, Stone EM, Zhang K, Pierce EA. 2007. The R345W mutation in EFEMP1 is pathogenic and causes AMD-like deposits in mice. Hum Mol Genet 16: 2411-2422.

Garland DL, Fernandez-Godino R, Kaur I, Speicher KD, Harnly JM, Lambris JD, Speicher DW, Pierce EA. 2013. Mouse genetics and proteomic analyses demonstrate a critical role for complement in a model of DHRD/ML, an inherited macular degeneration. Hum Mol Genet 23: $52-68$.

Glenn JV, Beattie JR, Barrett L, Frizzell N, Thorpe SR, Boulton ME, McGarvey JJ, Stitt AW. 2007. Confocal Raman microscopy can quantify advanced glycation end product (AGE) modifications in Bruch's membrane leading to accurate, nondestructive prediction of ocular aging. $F A$ SEB J 21: 3542-3552.

Glenn JV, Mahaffy H, Wu K, Smith G, Nagai R, Simpson DA, Boulton ME, Stitt AW. 2009. Advanced glycation end product (AGE) accumulation on Bruch's membrane: Links to age-related RPE dysfunction. Invest Ophthalmol Vis Sci 50: 441-451.

Goh SY, Cooper ME. 2008. Clinical review: The role of advanced glycation end products in progression and complications of diabetes. J Clin Endocrinol Metab 93: 11431152.

Gold B, Merriam JE, Zernant J, Hancox LS, Taiber AJ, Gehrs K, Cramer K, Neel J, Bergeron J, Barile GR, et al. 2006. Variation in factor $\mathrm{B}(B F)$ and complement component 2 (C2) genes is associated with age-related macular degeneration. Nat Genet 38: 458-462.

Goldberg MF. 1976. Bruch's membrane and vascular gowth. Invest Ophthalmol Vis Sci 15: 443-446.

Green WR, Enger C. 1993. Age-related macular degeneration histopathologic studies. The 1992 Lorenz E. Zimmerman Lecture. Ophthalmology 100: 1519-1535.

Gu X, Meer SG, Miyagi M, Rayborn ME, Hollyfield JG, Crabb JW, Salomon RG. 2003a. Carboxyethylpyrrole protein adducts and autoantibodies, biomarkers for agerelated macular degeneration. J Biol Chem 278: 4202742035.

Gu X, Sun M, Gugiu B, Hazen S, Crabb JW, Salomon RG. 2003b. Oxidatively truncated docosahexaenoate phospholipids: Total synthesis, generation, and peptide adduction chemistry. J Org Chem 68: 3749-3761.

Gu J, Paeur GJ, Yue X, Narendra U, Sturgill GM, Bena J, Gu X, Peachey NS, Salomon RG, Hagstrom SA, et al. 2009. Assessing susceptibility to age-related macular degeneration with proteomic and genomic biomarkers. Molecular \& Cellular Proteomics 8: 1338-1349.

Hageman G, Mullins R, Russell S, Johnson L, Anderson D. 1999. Vitronectin is a constituent of ocular drusen and the vitronectin gene is expressed in human retinal pigmented epithelial cells. FASEB J 13: 477-484.

Hageman GS, Anderson DH, Johnson LV, Hancox LS, Taiber AJ, Hardisty LI, Hageman JL, Stockman HA, Borchardt 
J.W. Crabb

JD, Gehrs KM, et al. 2005. A common haplotype in the complement regulatory gene factor $\mathrm{H}(\mathrm{HF} 1 / \mathrm{CFH})$ predisposes individuals to age-related macular degeneration. Proc Natl Acad Sci 102: 7227-7232.

Hageman GS, Luthert PJ, Victor Chong NH, Johnson LV, Anderson DH, Mullins RF. 2001. An integrated hypothesis that considers drusen as biomarkers of immune-mediated processes at the RPE-Bruch's membrane interface in aging and age-related macular degeneration. Prog Retin Eye Res 20: 705-732.

Hagenow K, Gelderman KA, Hultqvist M, Merky P, Backlund J, Frey O, Kamradt T, Holmdahl R. 2009. Ncf1-associated reduced oxidative burst promotes IL- $33 \mathrm{R}^{+} \mathrm{T}$ cell-mediated adjuvant-free arthritis in mice. J Immunol 183: $874-881$.

Haines J, Hauser M, Schmidt S, Scott W, Olson L, Gallins P, Spencer K, Kwan S, Noureddine M, Gilbert J, et al. 2005. Complement factor $\mathrm{H}$ variant increases the risk of agerelated macular degeneration. Science 308: 419-421.

Hammes HP, Hoerauf H, Alt A, Schleicher E, Clausen JT, Bretzel RG, Laqua H. 1999. N(ع)(Carboxymethyl)lysin and the AGE receptor RAGE colocalize in age-related macular degeneration. Invest Ophthalmol Vis Sci 40: 1855-1859.

Handa JT, Verzijl N, Matsunaga H, Aotaki-Keen A, Lutty GA, te Koppele JM, Miyata T, Hjelmeland LM. 1999. Increase in the advanced glycation end product pentosidine in Bruch's membrane with age. Invest Ophthalmol Vis Sci 40: 775-779.

Hazen SL. 2008. Oxidized phospholipids as endogenous pattern recognition ligands in innate immunity. J Biol Chem 283: 15527-15531.

Herold K, Moser B, Chen Y, Zeng S, Yan SF, Ramasamy R, Emond J, Clynes R, Schmidt AM. 2007. Receptor for advanced glycation end products (RAGE) in a dash to the rescue: Inflammatory signals gone awry in the primal response to stress. J Leukoc Biol 82: 204-212.

Hirata C, Nakano K, Nakamura N, Kitagawa Y, Shigeta H, Hasegawa G, Ogata M, Ikeda T, Sawa H, Nakamura K, et al. 1997. Advanced glycation end products induce expression of vascular endothelial growth factor by retinal Müller cells. Biochem Biophys Res Commun 236: $712-$ 715.

Hoffmann S, Friedrichs U, Eichler W, Rosenthal A, Wiedemann P. 2002. Advanced glycation end products induce choroidal endothelial cell proliferation, matrix metalloproteinase-2 and VEGF upregulation in vitro. Graefes Arch Clin Exp Ophthalmol 240: 996-1002.

Hollyfield JG, Bonilha VL, Rayborn ME, Yang X, Shadrach KG, Lu L, Ufret RL, Salomon RG, Perez VL. 2008. Oxidative damage-induced inflammation initiates age-related macular degeneration. Nat Med 14: 194-198.

Howes KA, Liu Y, Dunaief JL, Milam A, Frederick JM, Marks A, Baehr W. 2004. Receptor for advanced glycation end products and age-related macular degeneration. Invest Ophthalmol Vis Sci 45: 3713-3720.

Isas JM, Luibl V, Johnson LV, Kayed R, Wetzel R, Glabe CG, Langen R, Chen J. 2010. Soluble and mature amyloid fibrils in drusen deposits. Invest Ophthalmol Vis Sci 51: 1304-1310.

Ishibashi T, Murata T, Hangai M, Nagai R, Horiuchi S, Lopez PF, Hinton DR, Ryan SJ. 1998. Advanced glycation end products in age-related macular degeneration. Arch Ophthalmol 116: 1629-1632.

Jager R, Mieler W, Miller J. 2008. Age-related macular degeneration. N Engl J Med 358: 2606-2617.

Jiang H, Burdick D, Glabe CG, Cotman CW, Tenner AJ. 1994. $\beta$-Amyloid activates complement by binding to a specific region of the collagen-like domain of the Clq A chain. J Immunol 152: 5050-5059.

Jiang K, To E, Cui JZ, Cao SJG, Matsubara JA. 2012. Drusen and pro-inflammatory mediators in the post-mortem human eye. J Clinic Experiment Ophthalmol 3: 208-216.

Johnson LV. 2002. The Alzheimer's A $\beta$-peptide is deposited at sites of complement activation in pathologic deposits associated with aging and age-related macular degeneration. Proc Natl Acad Sci 99: 11830-11835.

Johnson LV, Ozaki S, Staples MK, Erickson PA, Anderson DH. 2000. A potential role for immune complex pathogenesis in drusen formation. Exp Eye Res 70: 441-449.

Johnson LV, Forest DL, Banna CD, Radeke CM, Maloney MA, Hu J, Spencer CN, Walker AM, Tsie MS, Bok D, et al. 2011. Cell culture model that mimics drusen formation and triggers complement activation associated with age-related macular degeneration. Proc Natl Acad Sci 108: 18277-18282.

Kamei M, Hollyfield JG. 1999. TIMP-3 in Bruch's membrane: Changes during aging and in age-related macular degeneration. Invest Ophthalmol Vis Sci 40: 2367-2375.

Kanda A, Chen W, Othman M, Branham KE, Brooks M, Khanna R, He S, Lyons R, Abecasis GR, Swaroop A. 2007. A variant of mitochondrial protein LOC387715/ ARMS2, not HTRA1, is strongly associated with age-related macular degeneration. Proc Natl Acad Sci 104: 16227-16232.

Kim SR, Jang YP, Jockusch S, Fishkin NE, Turro NJ, Sparrow JR. 2007. The all-trans-retinal dimer series of lipofuscin pigments in retinal pigment epithelial cells in a recessive Stargardt disease model. Proc Natl Acad Sci 104: 1927319278.

Klein R, Zeiss C, Chew E, Tsai J, Sackler R, Haynes C, Henning A, SanGiovanni J, Mane S, Mayne S, et al. 2005. Complement factor $\mathrm{H}$ polymorphism in age-related macular degeneration. Science 308: 385-389.

Knott AB, Perkins G, Schwarzenbacher R, Bossy-Wetzel E. 2008. Mitochondrial fragmentation in neurodegeneration. Nat Rev Neurosci 9: 505-518.

Liu Y, Walter S, Stagi M, Cherny D, Letiembre M, SchulzSchaeffer W, Heine H, Penke B, Neumann H, Fassbender K. 2005. LPS receptor (CD14): A receptor for phagocytosis of Alzheimer's amyloid peptide. Brain 128: 1778 1789.

Lotze MT, Zeh HJ, Rubartelli A, Sparvero LJ, Amoscato AA, Washburn NR, Devera ME, Liang X, Tor M, Billiar T. 2007. The grateful dead: Damage-associated molecular pattern molecules and reduction/oxidation regulate immunity. Immunol Rev 220: 60-81.

Lu M, Kuroki M, Amano S, Tolentino M, Keough K, Kim I, Bucala R, Adamis AP. 1998. Advanced glycation end products increase retinal vascular endothelial growth factor expression. J Clin Invest 101: 1219-1224.

Luibl V, Isas JM, Kayed R, Glabe CG, Langen R, Chen J. 2006. Drusen deposits associated with aging and age-related 
macular degeneration contain nonfibrillar amyloid oligomers. J Clin Invest 116: 378-385.

Malek G, Li CM, Guidry C, Medeiros NE, Curcio CA. 2003. Apolipoprotein B in cholesterol-containing drusen and basal deposits of human eyes with age-related maculopathy. Am J Pathol 162: 413-425.

Malek G, Johnson LV, Mace BE, Saloupis P, Schmechel DE, Rickman DW, Toth CA, Sullivan PM, Bowes Rickman C. 2005. Apolipoprotein E allele-dependent pathogenesis: A model for age-related retinal degeneration. Proc Natl Acad Sci 102: 11900-11905.

Marmorstein LY. 2002. Aberrant accumulation of EFEMP1 underlies drusen formation in Malattia Leventinese and age-related macular degeneration. Proc Natl Acad Sci 99: 13067-13072.

Marmorstein LY, McLaughlin PJ, Peachey NS, Sasaki T, Marmorstein AD. 2007. Formation and progression of subretinal pigment epithelium deposits in Efemp1 mutation knock-in mice: A model for the early pathogenic course of macular degeneration. Hum Mol Genet 16: $2423-$ 2432.

Matsue H, Edelbaum D, Shalhevet D, Mizumoto N, Yang C, Mummert ME, Oeda J, Masayasu H, Takashima A. 2003. Generation and function of reactive oxygen species in dendritic cells during antigen presentation. J Immunol 171: 3010-3018.

Michaelides M, Jenkins SA, Brantley MA Jr, Andrews RM, Waseem N, Luong V, Gregory-Evans K, Bhattacharya SS, Fitzke FW, Webster AR. 2006. Maculopathy due to the R345W substitution in fibulin-3: Distinct clinical features, disease variability, and extent of retinal dysfunction. Invest Ophthalmol Vis Sci 47: 3085-3097.

Mullins R, Russell S, Anderson D, Hageman G. 2000. Drusen associated with aging and age-related macular degeneration contain proteins common to extracellular deposits associated with atherosclerosis, elastosis, amyloidosis, and dense deposit disease. FASEB J 14: 835-846.

Ng KP, Gugiu B, Renganathan K, Davies MW, Gu X, Crabb JS, Kim SR, Rozanowska MB, Bonilha VL, Rayborn ME, et al. 2008. Retinal pigment epithelium lipofuscin proteomics. Mol Cell Proteomics 7: 1397-1405.

Ni J, Yuan X, Gu J, Yue X, Gu X, Nagaraj RH, Crabb JW, Group. TCGaPAS. 2009. Plasma protein pentosidine and carboxymethyllysine, biomarkers for age-related macular degeneration. Mol Cell Proteomics 8: 1921-1933.

Nordgaard CL, Karunadharma PP, Feng X, Olsen TW, Ferrington DA. 2008. Mitochondrial proteomics of the retinal pigment epithelium at progressive stages of agerelated macular degeneration. Invest Ophthalmol Vis Sci 49: 2848-2855.

Okamoto T, Tanaka S, Stan AC, Koike T, Kase M, Makita Z, Sawa H, Nagashima K. 2002. Advanced glycation end products induce angiogenesis in vivo. Microvasc Res 63: 186-195.

Panigrahi S, Ma Y, Hong L, Gao D, West XZ, Salomon RG, Byzova TV, Podrez EA. 2013. Engagement of platelet tolllike receptor 9 by novel endogenous ligands promotes platelet hyperreactivity and thrombosis. Circ Res 112: 103-112.

Penfold PL, Madigan MC, Gillies MC, Provis JM. 2001. Immunological and aetiological aspects of macular degeneration. Prog Retin Eye Res 20: 385-414.
Rivera A, Fisher SA, Fritsche LG, Keilhauer CN, Lichtner P, Meitinger T, Weber BH. 2005. Hypothetical LOC387715 is a second major susceptibility gene for age-related macular degeneration, contributing independently of complement factor $\mathrm{H}$ to disease risk. Hum Mol Genet 14: 3227-3236.

Rogers J, Cooper NR, Webster S, Schultz J, McGeer PL, Styren SD, Civin WH, Brachova L, Bradt B, Ward P, et al. 1992. Complement activation by $\beta$-amyloid in Alzheimer disease. Proc Natl Acad Sci 89: 10016-10020.

Sakaguchi H, Miyagi M, Shadrach KG, Rayborn ME, Crabb JW, Hollyfield JG. 2002. Clusterin is present in drusen in age-related macular degeneration. Exp Eye Res 74: $547-$ 549.

Sakai N, Decatur J, Nakanishi K, Eldred GE. 1996. Ocular age pigment "A2-E": An unprecedented pyridinium bisretinoid. J Am Chem Soc 118: 1559-1560.

Sarks S. 1976. Aging and degeneration in the macular region: A clinico-pathological study. Br J Ophthalmol 60: 324-328.

Sarks S, Cherepanoff S, Killingsworth M, Sarks J. 2007. Relationship of basal laminar deposit and membranous debris to the clinical presentation of early age-related macular degeneration. Invest Ophthalmol Vis Sci 48: 968-977.

Schmidt AM, Sahagan B, Nelson RB, Selmer J, Rothlein R, Bell JM. 2009. The role of RAGE in amyloid- $\beta$ peptidemediated pathology in Alzheimer's disease. Curr Opin Investig Drugs 10: 672-680.

Schutt F, Bergmann M, Holz FG, Kopitz J. 2003. Proteins modified by malondialdehyde, 4-hydroxynonenal, or advanced glycation end products in lipofuscin of human retinal pigment epithelium. Invest Ophthalmol Vis Sci 44: 3663-3668.

Seddon JM, Willett WC, Speizer FE, Hankinson SE. 1996. A prospective study of cigarette smoking and age-related macular degeneration in women. JAMA 276: 1141-1146.

Shaw PX, Zhang L, Zhang M, Du H, Zhao L, Lee C, Grob S, Lim SL, Hughes G, Lee J, et al. 2012. Complement factor $\mathrm{H}$ genotypes impact risk of age-related macular degeneration by interaction with oxidized phospholipids. Proc Natl Acad Sci 109: 13757-13762.

Shen JK, Dong A, Hackett SF, Bell WR, Green WR, Campochiaro PA. 2007. Oxidative damage in age-related macular degeneration. Histol Histopathol 22: 1301-1308.

Sparrow JR. 2007. RPE lipofuscin: formation, properties, and relevance to retinal degeneration. In Retinal Degenerations: Biology, Diagnostics and Therapeutics (ed. Tombran-Tink J, Barnstable CJ), pp. 213-236. Human Press, Totowa, NJ.

Sparrow JR, Boulton M. 2005. RPE lipofuscin and its role in retinal pathobiology. Exp Eye Res 80: 595-606.

Sparvero LJ, Asafu-Adjei D, Kang R, Tang D, Amin N, Im J, Rutledge R, Lin B, Amoscato AA, Zeh HJ, et al. 2009. RAGE (Receptor for Advanced Glycation Endproducts), RAGE ligands, and their role in cancer and inflammation. J Transl Med 7: 17.

Spraul C, Grossniklaus H. 1997. Characteristics of drusen and Bruch's membrane in postmortem eyes with age-related macular degeneration. Ophthalmology 115: 267-273. 
J.W. Crabb

Stone EM, Lotery AJ, Munier FL, Heon E, Piguet B, Guymer RH, Vandenburgh K, Cousin P, Nishimura D, Swiderski $\mathrm{RE}$, et al. 1999. A single EFEMP1 mutation associated with both Malattia Leventinese and Doyne honeycomb retinal dystrophy. Nat Genet 22: 199-202.

Stone EM, Braun TA, Russell SR, Kuehn MH, Lotery AJ Moore PA, Eastman CG, Casavant TL, Sheffield VC. 2004. Missense variations in the fibulin 5 gene and agerelated macular degeneration. $N$ Engl J Med 351: 346353.

Treins C, Giorgetti-Peraldi S, Murdaca J, Van Obberghen E. 2001. Regulation of vascular endothelial growth factor expression by advanced glycation end products. J Biol Chem 276: 43836-43841.

Umeda S, Suzuki M, Okamoto H, Ono F, Mizota A, Terao K, Yoshikawa Y, Tanaka Y, Iwata T. 2005. Molecular composition of drusen and possible involvement of anti-retinal autoimmunity in two different forms of macular degeneration in cynomolgus monkey (Macaca fascicularis). FASEB J 19: 1683-1685.

Urata Y, Yamaguchi M, Higashiyama Y, Ihara Y, Goto S, Kuwano M, Horiuchi S, Sumikawa K, Kondo T. 2002. Reactive oxygen species accelerate production of vascular endothelial growth factor by advanced glycation end products in RAW264.7 mouse macrophages. Free Radic Biol Med 32: 688-701.

Verhasselt V, Goldman M, Willems F. 1998. Oxidative stress up-regulates IL-8 and TNF- $\alpha$ synthesis by human dendritic cells. Eur J Immunol 28: 3886-3890.

Wang N, Anderson RE. 1992. Enrichment of polyunsaturated fatty acids from rat retinal pigment epithelium to rod outer segments. Curr Eye Res 11: 783-791.

Wang L, Clark M, Crossman D, Kojima K, Messinger J, Mobley J, Curcio C. 2010. Abundant lipid and protein components of drusen. PLoS ONE 5: e10329.

Weismann D, Hartvigsen K, Lauer N, Bennett KL, Scholl HP, Charbel Issa $\mathrm{P}$, Cano $\mathrm{M}$, Brandstatter $\mathrm{H}$, Tsimikas $\mathrm{S}$, Skerka C, et al. 2011. Complement factor H binds malondialdehyde epitopes and protects from oxidative stress. Nature 478: 76-81.

West XZ, Malinin NL, Merkulova AA, Tischenko M, Kerr BA, Borden EC, Podrez EA, Salomon RG, Byzova TV. 2010. Oxidative stress induces angiogenesis by activating
TLR2 with novel endogenous ligands. Nature 467: 972 976.

Wu Y, Yanase E, Feng X, Siegel MM, Sparrow JR. 2010. Structural characterization of bisretinoid A2E photocleavage products and implications for age-related macular degeneration. Proc Natl Acad Sci 107: 7275-7280.

Yang Z, Camp NJ, Sun H, Tong Z, Gibbs D, Cameron DJ, Chen H, Zhao Y, Pearson E, Li X, et al. 2006. Avariant of the HTRA1 gene increases susceptibility to age-related macular degeneration. Science 314: 992-993.

Yates J, Sepp T, Matharu B, Khan J, Thurlby D, Shahid H, Clayton D, Hayward C, Morgan J, Wright A, et al. 2007. Complement $\mathrm{C} 3$ variant and the risk of age-related macular degeneration. $N$ Engl J Med 357: 553-561.

Yoshida T, Ohno-Matsui K, Ichinose S, Sato T, Iwata N, Saido TC, Hisatomi T, Mochizuki M, Morita I. 2005. The potential role of amyloid $\beta$ in the pathogenesis of age-related macular degeneration. J Clin Invest 115: 2793-2800.

Yuan X, Gu X, Crabb JS, Yue X, Shadrach K, Hollyfield JG, Crabb JW. 2010. Quantitative proteomics: Comparison of the macular Bruch membrane/choroid complex from age-related macular degeneration and normal eyes. $\mathrm{Mol}$ Cell Proteomics 9: 1031-1046.

Zahringer U, Lindner B, Inamura S, Heine H, Alexander C. 2008. TLR2-promiscuous or specific? A critical re-evaluation of a receptor expressing apparent broad specificity. Immunobiology 213: 205-224.

Zarbin MA. 2004. Current concepts in the pathogenesis of age-related macular degeneration. Arch Ophthalmol 122: $598-614$.

Zareparsi S, Reddick AC, Branham KE, Moore KB, Jessup L, Thoms S, Smith-Wheelock M, Yashar BM, Swaroop A. 2004. Association of apolipoprotein E alleles with susceptibility to age-related macular degeneration in a large cohort from a single center. Invest Ophthalmol Vis Sci 45: 1306-1310.

Zareparsi S, Buraczynska M, Branham KE, Shah S, Eng D, Li M, Pawar H, Yashar BM, Moroi SE, Lichter PR, et al. 2005. Toll-like receptor 4 variant D299G is associated with susceptibility to age-related macular degeneration. Hum Mol Genet 14: 1449-1455. 


\section{$\&_{\mathrm{CSH}}^{\infty} \&$ Cold Spring Harbor

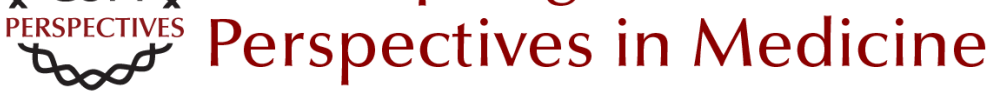

\section{The Proteomics of Drusen}

John W. Crabb

Cold Spring Harb Perspect Med 2014; doi: 10.1101/cshperspect.a017194 originally published online May 5,2014

\section{Subject Collection Retinal Disorders: Genetic Approaches to Diagnosis and Treatment}

Trial by "Firsts": Clinical Trial Design and Regulatory Considerations in the Development and Approval of the First AAV Gene Therapy Product in the United States

Kathleen Z. Reape and Katherine A. High

Immunology of Retinitis Pigmentosa and Gene Therapy-Associated Uveitis

Paul Yang, Debarshi Mustafi and Kathryn L. Pepple

Developing New Vectors for Retinal Gene Therapy Emilia A. Zin, Bilge E. Ozturk, Deniz Dalkara, et al.

Beyond the NEI-VFQ: Recent Experience in the Development and Utilization of Patient-Reported Outcomes for Inherited Retinal Diseases

Todd Durham, Judit Banhazi, Francesco Patalano, et al.

Electronic Retinal Prostheses

Daniel Palanker

Alternative RNA Splicing in the Retina: Insights and Perspectives

Casey J. Keuthan, Sadik Karma and Donald J. Zack

X-Linked Retinoschisis

Cristy A. Ku, Lisa W. Wei and Paul A. Sieving

A Systematic Review of Optogenetic Vision Restoration: History, Challenges, and New Inventions from Bench to Bedside

Antonia Stefanov and John G. Flannery
Lessons Learned from the Development of the First FDA-Approved Gene Therapy Drug, Voretigene Neparvovec-rzyl Jean Bennett and Albert M. Maguire

Therapeutic Gene Editing in Inherited Retinal Disorders Jinjie Ling, Laura A. Jenny, Ashley Zhou, et al.

Cell-Based Therapies: Strategies for Regeneration Marina Pavlou and Thomas A. Reh

The Importance of Natural History Studies in Inherited Retinal Diseases Allison Ayala, Janet Cheetham, Todd Durham, et al.

Photoreceptor Cell Replacement Using Pluripotent Stem Cells: Current Knowledge and Remaining Questions

Christelle Monville, Olivier Goureau and Karim Ben M'Barek

iPSC-RPE in Retinal Degeneration: Recent

Advancements and Future Perspectives

Tadao Maeda and Masayo Takahashi

Retinal Degeneration Animal Models in Bardet-

Biedl Syndrome and Related Ciliopathies Clarisse Delvallée and Hélène Dollfus

Mobility Testing and Other Performance-Based Assessments of Functional Vision in Patients with Inherited Retinal Disease

Daniel Chung, Colas Authié and Laure Blouin

For additional articles in this collection, see http://perspectivesinmedicine.cshlp.org/cgi/collection/ 
For additional articles in this collection, see http://perspectivesinmedicine.cshlp.org/cgi/collection/ 